\title{
Den svenske partisekreteraren och den mångnationella staten
}

Socialdemokrati och nation i Karl H. Wiiks politiska agerande under 1920-talet

Först måste vi göra oss av med den föreställningen, att allt sysslande med nationella spörsmål vore nationalism och något för en socialist ovärdigt. ${ }^{1}$

DEN HÄR ARTIKELN UNDERSÖKER HUR föreställningar kring nation och etnicitet kom till uttryck i den finländska socialdemokratin under I920-talet. Inte sällan anses nationalism och socialism utgöra varandras motsatser. Men senare forskning har visat att de är sammanflätade, då deras ursprung står att finna i en gemensam och samtida socialhistorisk, politisk-historisk och idéhistorisk kontext. Nationen var inte bara en abstrakt idé utan existerade konkret som en institution under I90o-talet. Nationalstaten var ett fungerande verktyg för arbetarrörelsen och en accepterad verksamhetsram inom vilken rörelsen kunde förverkliga sina politiska mål. Nationen hade både en viktig funktion för klasskampen och betydelse i sig för arbetarrörelsen. Arbetarrörelsens klasskamp har samtidigt kunnat innefatta nationell frigörelsekamp och bidragit till det ideologiska innehållet i nationalistiska rörelser och projekt. ${ }^{2}$

I. "Den svenska befolkningen i Finland: Vår nationalitetsfråga och socialdemokratins ställning till densamma. Referat av Karl H. Wiik på svenska soc.dem. kretsmötet i Helsingfors den 28 mars I92I", Arbetarbladet 8/4 I92I.

2. Jonas Ahlskog, Matias Kaihovirta \& Mats Wickström, "Nationen i klasskampen: Minoritetsnationalism inom den socialistiska arbetarrörelsen", Historisk Tidskrift 2018:3, Tema: Nationen, s. 452-458. 
Ett slags kortslutning i tanken har ändå uppstått hos dem som velat peka på socialismens och nationalismens olika väsen och motsättningarna mellan dem. Just därför är det viktigt att i stället utgå från att ideologier för det mesta har utarbetats som svar på samtida aktuella samhällsfrågor och verkat som drivkraft för människor att handla individuellt och kollektivt mot ett bestämt mål. ${ }^{3}$ Genom att rikta sökarljuset mot enskilda aktörer som lyckats förena nationalism och socialism i politiskt handlande kan vi öka förståelsen för dessa två idéers dragningskraft och ideologiernas förmåga att mobilisera människor till politisk handling både i det förflutna och i samtiden.

Min empiriska utgångspunkt i den här artikeln är att studera den svenskspråkige socialdemokratiske politikern Karl Harald Wiik (1883-1946) och hans syn på socialdemokratisk politik och nation. Min artikel är ett led i det ökade forskningsintresset för hur nationalismen skapats i olika historiska kontexter. I stället för att diskutera olika nationalismteoriers tillämpbarhet eller olika nationalistiska ideologiers förhållande till varandra, ligger intresset i nutida historieforskning om nationalism allt oftare på enskilda aktörers och gruppers skapande och reproduktion av nationalistisk ideologi och praktik. ${ }^{4}$

Samtidigt har nyare nationalismteorier bidragit till att problematisera tidigare historiska narrativ om nationalismen, till exempel genom att synliggöra nationalstatens hegemoni. Det som kan kallas kontrahegemoniska nationalismer - det vill säga nationalistiska idéer och rörelser som företräds av exempelvis etniska minoriteter eller politiska och sociala rörelser till höger eller vänster - visar att nationalstaten som politiskt projekt var omtvistad och att den skapades i ett politiskt kraftfält mellan olika rörelsers tolkning och syn på nationsfrågan. För delar av vänstern korsade nationsidén inte sällan frågor om klass, och på en del håll i världen har nationell frigörelsekamp sammanfallit med socialistisk klasskamp. ${ }^{5}$

3. Sheri Berman, The Primacy of Politics: Social Democracy and the Making of Europe's Twentieth Century, New York: Cambridge University Press 2006, s. 8-I2, https:// doi.org/ro.roi7/CBO97805II79IIo9.

4. Anne Berg, "Nationen i historien", Historisk Tidskrift 2018:3, Tema: Nationen, s. 383-39o.

5. Ahlskog, Kaihovirta \& Wickström, "Nationen i klasskampen", s. 456-463. 
I artikeln lägger jag primärt fokus på socialdemokratisk nationskonstruktion genom att undersöka K.H. Wiiks politiska agerande och tänkande. Föremål för undersökningen är Wiiks identifikation med det som kan kallas en finlandssvensk minoritetsnationalistisk och finländsk bi-nationell socialdemokrati som utvecklades under 1920-talet. Den ställs i relation till det då pågående finländska nationalstatsbygget och till dåtida transnationella nationalistiska och socialistiska idéer i den internationella socialdemokratiska arbetarrörelsen. Historikern Johanna Wassholm har definierat det analytiska begreppet identifikation som enligt henne "härstammar från samma rot som identitet, men som härlett från verbet får [...] en processuell konnotation som bättre fångar idén om att individen förändras och omformas i en ständig dialog med omgivningen [...]". ${ }^{6} \mathrm{I}$ artikeln lämnas det biografiska i bakgrunden och i stället är mitt fokus hur Wiik skapade och förmedlade politiska idéer kring socialism och nation och hur dessa idéer användes i dagspolitiken.

Socialdemokratins förhållande till den borgerliga nationalstaten har varit föremål för tidigare forskning. Men socialdemokratins relation till nationalism och föreställningar kring nationen, samt hur socialdemokraterna omfattade och utarbetade egna ideologiska ståndpunkter kring nationsidén under mellankrigstiden, har ägnats mindre intresse. Sociologen Carly Elizabeth Schall har studerat hur den svenska socialdemokratin skapade en klassöverskridande inkluderande politik som hade inslag av både etnisk (ethnic) och medborgerlig (civic) nationalism i partiets strävan att omvandla Sverige till ett nationellt folkhem för alla svenskar. Svenskheten framstod enligt Schall för de samtida som en icke-problematiserad naturlig nationell tillhörighet: alla som bodde i Sverige ansågs vara eller kunna bli svenskar. ${ }^{7}$

I Finland däremot präglades nationalstatsbygget av konflikten mellan finskt och svenskt, medan begreppet finländsk, som närmast

6. Johanna Wassholm, Svenskt, finskt och ryskt. Nationens, språkets och historiens dimensioner hos E. G. Ehrström I808-1835, Åbo: Åbo Akademis förlag 2008, s. I3. Finns även elektroniskt, https://www.doria.fi/bitstream/handle/Ioo24/33682/WassholmJohanna.pdf?sequence=2\&isAllowed=y (hämtad $7 / 4$ 2020).

7. Carly E. Schall, "(Social) Democracy in the blood? Civic and ethnic idioms of nation and the consolidation of Swedish social democratic power, I928-I932", Journal of Historical Sociology, Vol. 25 No. 3 September 20I2, s. 46I-463, 469-470, https://doi.org/Io.IIII/j.I467-6443.20I2.0I428.x. 
utgjorde en bi-nationell medborgarnationalistisk konstruktion, var starkt ifrågasatt av de samtida politiska aktörerna. Utgångspunkten för finländsk socialdemokrati framstod, i jämförelse med den i Sverige, som mera problematisk på grund av inbördeskrigets tudelning av befolkningen och språkstriden - men framför allt på grund av att Finland inte var lika etniskt homogent under mellankrigstiden som Sverige. Finlands socialdemokratiska parti (SDP) har i tidigare forskning framställts som neutralt i "språkfrågan", en tolkning som ligger i linje dels med partiets officiella språkpolitik enligt vilken man accepterade Finlands tvåspråkighet, dels med framträdande partiledares, såsom Väinö Tanners, ofta försonliga inställning under språkstriden. Men i själva verket var språkfrågan ytterst omdiskuterad i SDP, både före och efter partiets språkpolitiska ställningstagande I906. Språkfrågan väckte debatt inom partiet, ofta till exempel i anslutning till centrala spörsmål som gällde hur socialdemokraterna förhöll sig till nationalstatens utformning. Historikern Niko Kannisto har med stöd i nutida nationalismforskning diskuterat det finländska SDP:s förhållande till den finländska nationalstatsnationalismen åren I9I8-I930, men han intar en försiktig - för att inte säga avfärdande - inställning till den etniska dimensionen i hur socialdemokraterna förhöll sig till tidens gängse nationalismer i Finland. Han synliggör inte heller den finlandssvenska socialdemokratin och vänstern och dess inverkan på den finländska socialdemokratins förhållande till nationen och nationalstaten. ${ }^{8}$

I artikeln avser jag visa vilken roll föreställningar kring nation spelade i Wiiks formulering av socialdemokrati. Vilken betydelse hade det samtida idéutbytet kring frågor gällande nation och socialism för Wiik? Hur påverkade etnonationalistiska och rentav rasistiska förhållningssätt till nation och socialism Wiiks politiska agerande? Vilken betydelse hade internationalism i Wiiks politiska retorik, ett begrepp lanserat av den internationella socialdemokratiska arbetarrörelsen? Ett hurdant mottagande fick Wiik och hans tänkande i den samtida politiska kontexten, där kampen om tolkningsföreträde i frågan vilka

8. Niko Kannisto, Vaaleanpunainen tasavalta. SDP, itsenäisyys ja kansallisen ybtenäisyyden kysymys vuosina 19I8-1924, Tampere: Työväen historian ja perinteen tutkimuksen seura 2016. 
som tillhörde den finländska nationalstaten pågick? Källmaterialet för artikeln är texter författade av och om Wiik och består av brev, tal och tidningsartiklar. Artikelns metod bygger på ett synliggörande av aktörens roll och användning av samtida diskurser om socialism och nationalism i en samhällshistorisk kontext. ${ }^{9}$ Artikeln visar hur Wiik använde samtida diskurser om nation i det konkreta politiska arbete som han utförde i den finländska socialdemokratiska arbetarrörelsen under den studerade tidsperioden.

\section{SDP:S SVENSKE PARTISEKRETERARE}

Karl H. Wiik utsågs enhälligt till ny partisekreterare för SDP på partikongressen den I-6 februari 1926. För övrigt karaktäriserades partikongressen av den laddade konflikt som pågick mellan partiordförande Väinö Tanner och partiets vänsteropposition. Under kongressen gick de oppositionella segrande ur striden. Wiik hade av oppositionen tillfrågats att bli partisekreterare och hans utnämning blev hans återkomst till den socialdemokratiska partiledningen. Sex år tidigare hade Wiik frivilligt lämnat partistyrelsen i protest mot SDP:s beslut att motsätta sig Ålands anslutning till Sverige. Wiik och Finlands svenska arbetarförbund (FSA) hade däremot försvarat ålänningarnas irredentism. Författaren till K.H. Wiiks biografi Erkki Tuomioja verkar dock inte godta Wiiks egen förklaring att han lämnade partistyrelsen 1920 på grund av SDP:s "imperialistiska politik" i förhållande till Ålandsfrågan, och han hänvisar i stället till Wiiks personliga schismer med Tanner. ${ }^{10}$

Wiik verkade både som flitig ledarskribent och sedermera under en kort tid som Arbetarbladets huvudredaktör just under den period då Ålandsfrågan diskuterades. Wiik och FSA ställde sig som sagt på ålänningarnas sida, och deras försvar av ålänningarnas minoritetsnationella rättigheter var samtidigt en rungande kritik av den vita borgerliga finska statens "imperialism" och förtryck av minoriteter. Arbetarbladet framförde kritiken mot "vår unga finska republik" som

9. Ahlskog, Kaihovirta \& Wickström,"Nationen i klasskampen", s. 456.

Io. Erkki Tuomioja, K.H. Wiik:puoluesibteeri ja oppositiososialisti 2. Elämäkerta I9I8-1946, Helsinki: Tammi I982, s. 52-56, 72-77. 
enligt ledarskribenten nu åter "dokumenterat sig som en stat, som icke hör hemma inom den skandinaviska eller överhuvudtaget västerländska kulturzonen". ${ }^{11}$ Argumenteringen följde en linje som särskilt Wiik hade utstakat i tidigare inlägg i Arbetarbladet: kampen mellan västerländsk och österländsk civilisation, där socialdemokraterna kämpade mot österländsk reaktion och för västerländsk demokrati. "[V]i har för länge levat samman med östern för att ha hunnit helt övervinna verkningarna därav [...]", skrev Wiik. ${ }^{12}$

I ljuset av Wiiks tidigare och samtida ställningstaganden i nationsfrågan och särskilt hans kritik av en "chauvinistisk" och "imperialistisk" finsk majoritetsnationalism, som även SDP enligt Wiik verkade hemfalla åt, försökte han verka för socialistisk internationalism. Den socialistiska internationalism som Wiik stod för representerade en försonlig linje som uppstått efter en upprivande konflikt mellan finska och svenska socialdemokrater i den finländska arbetarrörelsen I906. Då hade Wiiks socialistiska, svenska minoritetsnationalism gjort honom känd på nationell nivå. Tillsammans med studiekamraten och socialdemokraten Filemon Tiderman tog Wiik initiativet till att grunda ett självständigt svenskt socialdemokratiskt parti i Finland. Partiet behövdes, menade Wiik, eftersom ”[d]e svenska arbetarena äro mera betänksamma, mindre hänförda, hafva mer förmåga till kritik än till hastiga initiativ [...]”, medan man på finskt håll hade en "stark hänförelse för idéerna", som enligt Wiik ofta stod "parad med omdömeslöshet". Skillnaderna i de två nationaliteternas karaktär och kulturella utvecklingsnivå fick Wiik att slå vakt om de svenska arbetarnas rätt till ett eget parti och att agera som en självständig svensk distriktsorganisation inom SDP. ${ }^{13}$ På FSA:s representantmöte, den första förbundskongressen, debatterade man partigrundandet. Under debatten framlade Wiik det som även senare skulle stå som hans kritik av den finska majoritetsnationalismen - det som I906, av dess svenska minoritetsnationalistiska kritiker, kallades för "suometarianism" och senare under mellankrigstiden för "äktfinskhet":

\footnotetext{
II. "Ålandsfrågan", Arbetarbladet I7/6 I920. Min kursiv.

I2. K.H. Wiik, "Den sociala kampen i Estland", Arbetarbladet I9/8 I920.

I3. Karl H. Wiik, "Ett svenskt socialdemokratiskt parti i Finland?", Arbetaren 26/5 I906.
} 
Hvad är i själfva verket suometarianismen? Dess rot är på bortre sidan Ural, medan den moderna arbetarrörelsen är en kulturell rörelse af vesterländskt ursprung. Suometarianismens ande består i kryperi för de mäktigare och förtryck mot de svagare $[\ldots]{ }^{14}$

Vad som följaktligen är av intresse i citatet, för att belysa Wiiks socialistiska svenska minoritetsnationalism och dess betydelse för hans senare argumentering, är hans beskrivning av den finska majoritetsnationalismen som ett hot mot den svenskspråkiga minoritetens rättigheter."Suometarianismen”, som 1906 syftade på fennomanin representerad av Gammalfinska partiet och i senare språkbruk på äktfinskhet, låg enligt Wiik på en lägre kulturell utvecklingsnivå. Wiik underströk socialismens västerländskhet. För Wiik representerade fennomanins finsknationalism den österländska civilisationen, som med sin auktoritära barbarism och sedd ur ett västerländskt eurocentriskt perspektiv framstod som motsatsen till västerlandets demokrati och civilisation.

Wiiks minoritetsnationalistiska partiplaner fick ändå ge vika då majoriteten i FSA motsatte sig förslaget och i stället önskade att tillhöra ett gemensamt parti med de finska socialdemokraterna. ${ }^{15}$ SDP:s resolution i nationalitetsfrågan på partikongressen i Uleåborg $\mathrm{i}$ augusti I906 blev lösningen på den nationskonflikt som hotade den finländska arbetarrörelsens enighet. I resolutionen framställdes de finska, svenska och ryska nationaliteterna som med varandra jämbördiga och gavs rätt att utvecklas på egna villkor men utan att förtrycka andra nationaliteter. Partikongressen bestämde att de olika nationaliteterna skulle få verka i egna inom partiet verksamma nationalitetsorganisationer, för de svenskspråkiga socialdemokraternas del FSA, och inneha en stadigvarande representation i partiets styrande organ. Resolutionen och de uttalanden som gjordes på partikongressen följde den internationella socialdemokratiska arbetarrörelsens ställningstaganden i frågan om

I4. "Protokoll fördt vid de svenska arbetarenas representantmöte i Helsingfors I4, I5 och I6 juli 1906", CA:I Förbundskongressprotokoll, FSD:s arkiv, Arbetararkivet (TYARK), Helsingfors.

15. Anna Bondestam \& Alf-Erik Helsing, Som en stubbe i en stubbåker. Finlands svenska arbetarförbund I899-1974, Helsingfors: Finlands svenska arbetarförbund I978, s. 39, $43-45,47-48$. 
nationernas rätt till självbestämmande. ${ }^{16}$ Enligt Wiik skulle SDP:s ställningstagande avpolitisera nationalitetsfrågan och I9I9, då den nya nationalstatens bi-nationella (tvåspråkiga) regeringsform godkändes i riksdagen, framhöll Wiik att lösningen var samstämmig med de ställningstaganden som SDP redan hade gjort på partikongressen i Uleåborg 1906. ${ }^{17}$ Här kan Wiiks tolkning förstås utifrån partiets syn på det svenska i Finland, såsom den hade framlagts i partikongressens resolution år 1906: "det svenska språket är nödvändigt för den svenska befolkningens allsidiga förkovran och dessutom av stor betydelse för den västerländska kulturens och de socialdemokratiska idéernas spridning i Finland [...]."18

Wiiks förhållande till nationsfrågan under I920-talet kan ses utifrån de österrikiska socialdemokraternas, de så kallade austromarxisternas, starka ställning i den förnyade internationella socialdemokratiska arbetarrörelsen som uppstod ur den splittrade socialistiska Andra internationalen. Austromarxisterna var en förebild för många utländska socialdemokrater. De hade lanserat ett mycket ambitiöst socialpolitiskt reformprogram för den mångetniska staden Wien, och även framfört en socialdemokratisk lösning på de etniska konflikterna i de nya mångnationella arvtagarstaterna till de tidigare central- och östeuropeiska imperierna som gått under efter första världskriget. Austromarxisterna Otto Bauers och Karl Renners huvudtes var att betrakta nationen som en "ödesgemenskap" som förenat människor med samma språk, kultur, ras och historia till en kollektiv"karaktärsgemenskap". Nationen var enligt dem en del av den sociala verkligheten och måste därför accepteras av socialisterna. Då nationen betraktades som en kulturell gemenskap utgjorde den inte heller en egen samhällsfråga, vilket innebar att nationen inte kunde utgöra grund för en statsbildning. Att avskilja nation från stat var austromarxisternas försök att avpolitisera nationsfrågan och göra den till en kulturell fråga som kunde underställas statens styrning av samhället. ${ }^{19}$

I6. Hannu Soikkanen, Sosialismin tulo Suomeen. Ensimmäisiin yksikamarisen eduskunnan vaaleibin asti, Helsinki: WSOY i961, s. 293-294.

I7. K.W. [Karl H. Wiik], ”Den svenska befolkningens ställning tryggad", Arbetarbladet $23 / 7$ I9I9.

18. Bondestam \& Helsing, Som en stubbe i en stubbåker, s. 48.

I9. John Schwarzmantel,"Karl Renner and the problems of multiculturalism”, Ephraim 
Genom att avpolitisera nationsfrågan kunde arbetarrörelsen fokusera på den primära politiska frågan, nämligen klasskampen mellan arbetar- och borgarklass. Förskjutningarna i klassförhållandena avgjorde vilken samhällsklass som styrde staten. Samtidigt erbjöd austromarxisterna en rätt liberal lösning på nationskonflikterna då de ansåg att det var upp till individen själv att avgöra vilken nationsgemenskap hen önskade tillhöra. En tredje punkt av betydelse för stater med en mångnationell befolkning var att nationen inte nödvändigtvis var bunden till ett särskilt territorium, utan nationella kulturella karaktärsdrag var något som individer och kollektiv bar med sig vart än de begav sig. Den socialistiska staten garanterade i sin tur varje nations rätt att existera inom statsgemenskapen utifrån arbetarrörelsens principer om internationell solidaritet. ${ }^{20}$

Det som ledde till att Wiik och samtliga socialister problematiserade borgerlighetens nationsbegrepp var att det inom nationerna fanns klasskillnader som inte borgerligheten ville kännas vid - vilket i sin tur resulterade $i$ att arbetarklassen inte kunde identifiera sig med den borgerliga bilden av nationen som kollektiv gemenskap. Samtidigt pekade Wiik på att socialdemokratins svaga ställning bland finlandssvenskarna inte berodde på minoritetens borgerlighet eller på att finlandssvenskarna var reaktionärt antidemokratiska, utan orsaken stod att finna i den mäktiga svenskspråkiga överklassens förtryck av det finlandssvenska folket. ${ }^{21}$

Under 1920-talet präglade inbördeskrigets hårda erfarenheter den svenskspråkiga arbetarklassens villkor. I SDP:s 25-årshistorik, där Wiik redogjorde för "Socialdemokratin bland Finlands svenskar", hävdade han att "terrorn på svenskspråkiga orter varit mera brutal än på annat håll, då den svenska överklassen var mera obarmhärtig”. Wiik påstod därmed att den svenska överklassen hade straffat de finlandssvenska röda särskilt hårt, och han antydde att detta gjordes för att utplåna arbetarrörelsen på svenskt håll i Finland. Wiik framhöll vidare att man på finlandssvenskt håll saknade ett borgerligt svenskt-liberalt eller demokratiskt parti som kunde motverka den svenska högerns

Nimni (ed.), National-Cultural Autonomy and its Contemporary Critics, London:

Routledge 2005 , s. 54-56.

20. Ibid., s. 54-55.

2I. "Arbetarens I maj", Arbetaren 4/5 I907. 
reaktionära klasspolitik; arbetarklassen var därmed helt utlämnad åt den svenskspråkiga överklassens förtryck. ${ }^{22}$ I och med att svenskheten i Finland framstod som mera reaktionär och antidemokratisk, vilket Wiik ofta påpekat, hade den mött motstånd bland de demokratiskt sinnade i den finskspråkiga majoriteten. Wiik menade att den svenskspråkiga överklassens antidemokratiska inställning var en skam för svenskheten och den svenskspråkiga minoritetens flertal i Finland. Överklassen hotade framställa alla svenskar i Finland som en reaktionär nationell minoritet, vilket i sin tur skadade förhållandet mellan den finskspråkiga majoriteten och den svenskspråkiga minoriteten. ${ }^{23}$

\section{"DEN OFOSTERLÄNDSKA KOALITIONEN" MOT \\ "DEN FINSKA BORGARKLASSENS OPPOSITION"}

SDP:s regeringsmedverkan hade ältats både på socialdemokratiskt och borgerligt håll efter inbördeskriget. De borgerliga och särskilt högern hyste stor misstänksamhet mot socialdemokraterna efter I918, och socialdemokraternas inställning till de borgerliga partierna var snarlik. Partikongresserna efter inbördeskriget hade fastställt principen att SDP kunde medverka i koalitionsregeringar med de borgerliga endast i undantagssituationer, men i samband med kongressen 1926 omvärderades tidigare beslut kring regeringsmedverkan. Partiet ställde sig nu positivt till regeringssamarbete med de borgerliga partierna. Omvärderingen var möjlig då särskilt partiets vänsterfalang och center (som Wiik räknades till), vilka tidigare motsatt sig regeringsmedverkan, godtog att socialdemokrater skulle kunna regera tillsammans med en borgerlig center. Detta kunde godtas utifrån den "centerpolitiska strategin", som utformats av Socialistiska Arbetarinternationalen (SAI). ${ }^{24}$

22. Karl H. Wiik, "Sosialidemokratia Suomen ruotsalaisten keskuudessa", Sosialidemokraattinen puolue 25 vuotta, Helsinki: Sosialidemokraattinen puoluetoimikunta I924, s. 268-270.

23. Ibid., s. 27I-272; K.H. Wiiks förstamajtal I907, "Arbetarens I maj”, Arbetaren 4/5 1907.

24. Pauli Kettunen, Poliittinen liike ja sosiaalinen kollektiivisuus. Tutkimus sosialidemokratiasta ja ammattiyhdistysliikkeestä Suomessa I9I8-1930, Helsinki: Suomen Historiallinen Seura I986, s. 283-306. 
Den finländska högerns ryggrad hade alltsedan I9I8 varit Samlingspartiet och Svenska folkpartiet (SFP). Men samtidigt var bägge splittrade partier. Det som splittrade den finländska högern var svenskans ställning i Finland, vilket gav SDP:s centerpolitiker en möjlighet att inleda samarbete med SFP för att ytterligare försvaga högerns maktposition. SFP:s konservativa högerfalang utmanades av den gruppering som kallades Svenska vänstern, som bildade en självständig partifraktion efter inbördeskriget. Till dess förgrundsgestalter räknades bland andra Georg Schauman och Max Hanemann, bägge bekanta med Wiik från de radikala och ungdomliga studentåren i början av I9oo-talet. Hanemann hade tillfälligt verkat i FSA samtidigt som Wiik vid tiden strax före storstrejken I905 och Schauman "räknades också till denna meningsinriktning", enligt Gunnar Landtman. Landtman syftar på den "sociala klubb" som omfattade svenska studenter med sympatier för arbetarrörelsen. ${ }^{25}$ Onekligen förbättrades relationen mellan SFP och SDP då SDP:s partisekreterare var gammal bekant med framträdande representanter för SFP:s vänsterfraktion, samtidigt som dessa personer i många avseenden hade samma syn på svenska minoritetsrättigheter och behovet av sociala reformer bland de svenskspråkiga. Men samtidigt var Wiik inte inne på SFP:s linje i dess minoritetsnationalistiska strävanden att införa svenska självstyrande kantoner enligt schweizisk modell, vilket var ett seriöst förslag som fördes fram inom SFP och som livligt debatterades på finlandssvenskt håll åren efter självständigheten. ${ }^{26}$

Efter att Wiik tillträtt som partisekreterare uttalade han sin kritik av den svenska självstyrelsetanken i ett tal i Gamlakarleby, för en "för ortsförhållandena talrik åhörarskara, bland vilken märktes flera på borgerligt håll tongivande personer". ${ }^{27}$ Wiik underströk att SDP "avgörande påverkat lagstiftningen på ett sätt" som tillgodosåg "det svenska mindretalets berättigade krav". Tack vare partiets internatio-

25. Gunnar Landtman, Studenter under Finlands kampår I898-1909, Skrifter utgivna av Svenska litteratursällskapet i Finland 280, Helsingfors: Svenska litteratursällskapet i Finland 1940, s. 394; Bondestam \& Helsing, Som en stubbe i en stubbåker, s. 34; Göran von Bonsdorff \& Frank Jernström, Svenska folkpartiet 2. I9I7-I929: Från självständighet till Lappo, Helsingfors: Svenska folkpartiet r.p. I984, s. I55-I58.

26. von Bonsdorff \& Jernström, Svenska folkpartiet 2, s. 37-77.

27. "Socialdemokratin och nationalitetsfrågan", Arbetarbladet 24/3 1926. 
nalism var SDP villigt att överbrygga tidigare rivaliteter mellan de två nationaliteterna. Men efter regeringsformens och språklagarnas instiftande hade minoritetsnationalismen åter höjt sitt huvud med SFP:s krav på svenskt självstyre enligt åländsk modell:

Gentemot den rent nationalistiska riktning, som vill med en oöverstiglig kinesisk mur avstänga den svenska befolkningen från den finska och vilken riktning har sina anhängare främst bland bönderna samt dem närstående element (folkskollärare o.dyl.), står en del överklasselements strävan till samarbete med de finska borgerliga partierna i syfte att åt den svenska överklassen bevara inflytande på landets allmänna angelägenheter. ${ }^{28}$

De "samhällselement" som Wiik nämnde i sitt tal skulle göras medvetna om att deras minoritetsnationalistiska strävanden inte sammanföll med överklassens. I stället gynnades den svenska befolkningen enligt Wiik av att"fördomsfritt och vaket taga del i det demokratiska reformarbetet". Här hänvisade Wiik till SDP:s planer på socialförsäkringar för samtliga finländare, en omfattande socialpolitisk reform som skulle gälla även den svenska befolkningen. Förslaget kunde inte förverkligas ifall finlandssvenskarna slöt sig inom egna kantoner där SFP skulle ha en majoritetsställning och där den svenska överklassen, som företräddes av partiets högerfalang, skulle göra sitt yttersta för att motverka dylika för överklassen kostsamma sociala reformer. ${ }^{29}$

Wiiks kritik av den svenska överklassens försök att kvarhålla sitt inflytande i finländsk politik, genom att försöka samarbeta med den finskspråkiga borgerligheten och när detta misslyckats, försöka samarbeta med SDP, hade två syften. Det första syftet var att utnyttja SFP:s inre splittring mellan partiets socialliberala vänster, som föredrog samarbete med mittenpartierna och SDP framom den finska högern, och partiets högerfraktion vars primära målsättning var att hålla vänsterpartierna utanför allt politiskt inflytande i republiken. Det överensstämde med SDP:s centerpolitiska strategi att utnyttja sprickan mellan de finländska borgerliga partierna. Det andra syftet

28. Ibid.

29. Ibid. 
som framgår i Wiiks tal var att lägga fram SDP:s och Wiiks egen syn på nationsfrågan som skilde sig från SFP:s borgerliga minoritetsnationalism. Wiik hörde till dem inom SDP som inte såg på den centerpolitiska strategin som en reaktiv hållning och ett försvar mot högern utan som en aktiv socialdemokratisk strategi där partiet inte avsåg tumma på sina politiska reformkrav för att vinna de borgerliga mittenpartiernas, eller i det här fallet SFP:s, gunst. Wiik kritiserade både SFP:s "bygdesvenska" minoritetsnationalister för att de strävade efter att med en "oöverstiglig kinesisk mur avstänga den svenska befolkningen från den finska", och den svenskspråkiga elitens syfte "att åt den svenska överklassen bevara inflytande på landets allmänna angelägenheter”. ${ }^{30}$ SDP:s förhållande till nationalitetsfrågan hade ju enligt Wiik redan fått sin lösning med regeringsformen I9I9 och språklagarna i922. Det som går att utläsa i Wiiks syn på nationalitetsfrågan beträffande hur den skilde sig från SFP:s minoritetsnationalism och den äktfinska majoritetsnationalismen är att den hade drag av det austromarxistiska synsättet: nationsfrågan var inte längre en politisk fråga eftersom den hade fătt sin lösning genom lagstiftning och var underställd statsmakten. Wiik strävade efter att peka på att det bakom SFP:s tal om självstyrelse i själva verket låg en klasspolitik som kännetecknade överklassen, bondeklassen och "dess närstående element". Denna klasspolitik gick ut på att hindra socialdemokraterna från att förverkliga sin reformpolitik genom att förtrycka den svenska arbetarklassen och slå en kil mellan svenskspråkiga och finskspråkiga arbetare. Klasskampen var därmed den verkliga politiska tvistefrågan i samhället, enligt Wiik.

Den 22 november 1926 konkretiserades samarbetet mellan SDP och SFP då den finskborgerliga regeringen Kallio störtades till följd av en interpellation av SFP i riksdagen med svenska vänsterns Schauman som första undertecknare. Interpellationen gällde oegentligheter i samband med leveranser från en ammunitionsfabrik i Riihimäki. Men som SFP framhöll, var interpellationen i första hand en manöver för att slutligen avsätta Kallio som statsminister, då dennes regering blivit ytterst impopulär inom partiet för sin påstådda anti-svenskhet. President Relander gav uppdraget att bilda ny regering till SDP och

3o. Ibid. 
dess avgångne partiordförande Väinö Tanner, som vid tidpunkten verkade som den socialdemokratiska riksdagsgruppens ordförande. Den 13 december 1926 bildades således den första socialdemokratiska minoritetsregeringen under Finlands självständighet med Tanner som statsminister. Regeringen Tanners starkaste flankstöd i riksdagen blev SFP, samtidigt som partiet även avgjorde regeringens öde då det sedermera röstade för dess avgång den I7 december 1927 . Under regeringens ettåriga period vid makten fick regeringen även stöd av majoriteten av framstegspartiets riksdagsledamöter och vänstersocialisterna. ${ }^{31}$

Det som på finskt borgerligt håll väckte kritik mot regeringsdeklarationen var den socialdemokratiska minoritetsregeringens syn på nationalitetsfrågan:

I fråga om förhållandet till nationella minoriteter har den internationella socialdemokratin omfattat ett visst redan stadgat förfarande. I enlighet därmed skall regeringen $i$ avseende å landets svenska mindretal bedriva en rättvis och opartisk politik i regeringsformens anda. ${ }^{32}$

Statsvetaren Sven Lindman poängterar att Tanners regering, till den finska borgerlighetens förtret, i hög grad gick SFP till mötes, då SDP använde den "på svenskt håll hyllade åsikten om en faktisk nationalitetsåtskillnad, ej blott språkolikhet, mellan landets båda språkgrupper". ${ }^{33}$ Tanners regeringsdeklaration hade emellertid inte bara syftet att göra "ett gott intryck i det svenska lägret", utan den var även i linje med Wiiks och SDP:s ställningstaganden i nationalitetsfrågan.

Till partisekreteraruppdraget hörde uppgiften att upprätthålla kontakten mellan partiet och SAI:s byrå i Bryssel. Under Tanners regeringstid korresponderade Wiik aktivt med SAI:s generalsekreterare, austromarxisten Friedrich Adler. Wiik framlade de ideologiska och politiska ståndpunkterna bakom den finländska socialdemokratiska regeringspolitiken. Han betonade att regeringen Tanner av den finska högern karakteriserats som "den ofosterländska koalitionen", högerns

3I. Sven Lindman, De homogena partiregeringarna i Finland 1926-I928. I. Det socialdemokratiska regeringsexperimentet 1926-I927, Åbo: Åbo Akademi I940, s. II-2I, $59-65$.

32. Ibid., s. 24 .

33. Ibid. Min kursiv. 
pejorativa uttryck för regeringsfronten i riksdagen som Wiik då tycktes omfamna. För Adler beskrev Wiik regeringen som ett"skydd mot de chauvinistiska tendenser som återfanns hos den finska borgerligheten”. Som argument för detta nämnde Wiik det slags aggressiva politik de finskspråkiga borgerliga partierna fört inte bara mot arbetarklassen utan även mot den svenskspråkiga minoriteten i Finland. Politiken hade de senaste åren kommit till uttryck i en lagstiftning som diskriminerade finlandssvenskar, menade Wiik. ${ }^{34}$

I juli I927 ordnades ett riksdagsval som utföll i en valseger för regeringen och dess stödpartier. Den socialdemokratiska valkampanjen blev Wiiks första stora eldprov som ansvarig för partiets valorganisation. I socialdemokraternas kampanj uppmanades svenska väljare att lägga sin röst antingen på SDP eller SFP för att förhindra ett "äktfinskt korståg" mot svenskheten. ${ }^{35}$ Att svenskspråkiga socialdemokrater uppmuntrades rösta på SFP var uppseendeväckande, men förståeligt utifrån socialdemokraternas vilja att hålla den tannerska regeringen vid liv och garantera dess stöd i riksdagen även efter valet. Efter valet rapporterade en belåten Wiik till SAI att väljarna i riksdagsvalet, trots det "finsknationella" samlingspartiets försök att störta regeringen, hade "berett den finsk-borgerliga reaktionen ett smärtsamt nederlag”. Försvaret av den svenska minoriteten var tills vidare tryggat med det för regeringsfronten positiva valresultatet, skrev Wiik, och stödet från SFP skulle avvärja "den finsk-borgerliga reaktionens" angrepp mot demokratin. ${ }^{36}$ Men samtidigt erkände Wiik utmaningarna för den "demokratiska fronten", och medgav att denna front var svag. De olika synerna på klassfrågan mellan SDP och det "högborgerliga" SFP skilde partierna åt och i dessa frågor hade SFP mera gemensamt med de "chauvinistiska" finsk-borgerliga partierna än med SDP och kommunisterna. ${ }^{37}$

I Sverige drabbades SDP:s socialdemokratiska broderparti Socialdemokratiska Arbetarpartiet (SAP) av ett valnederlag I928 och par-

34. K.H. Wiik till Friedrich Adler II/5 I927, K.H. Wiiks korrespondens I923-I937, SDP:s arkiv, Arbetararkivet, Helsingfors.

35. Arbetarbladet, $29 / 6$ I927.

36. K.H. Wiik till SAI, odaterat I927, K.H. Wiiks korrespondens I923-I937, SDP:s arkiv, Arbetararkivet, Helsingfors.

37. Wiik till Friedrich Adler II/5 I927. 
tiet gjorde en slutlig kursändring från klasskampsideologin till den sedermera välkända reformistiska folkhemsideologin, manifesterad bland annat i den socialdemokratiska partiledaren Per Albin Hanssons berömda "folkhemstal" samma år. Hanssons tal om det goda folkhemmet var ett eko från tidigare nationalistisk och konservativ retorik, men innehöll även ideologiska intryck från austromarxismens nationalism som spridit sig bland socialdemokrater verksamma i SAI. Bland andra Wiiks svenska partisekreterarkollega Rikhard Lindström, som inom SAP var en av de ideologiska arkitekterna bakom den nationalistiska folkhemsretoriken i partiets socialreformistiska politik, hade lanserat begreppet nationell socialism i svensk socialdemokrati. I sin bok Socialism, nation och stat (I928) ${ }^{38}$ citerade han flitigt Otto Bauer. Wiik höll kontakt med Lindström men mera på kollegial basis än att de skulle ha varit ideologiska meningsfränder, då de två klart hade olika syn på socialistisk nationalism. Wiik vägrade att överge de marxistiska klasskampsdogmer som Lindström å sin sida ville utradera från sitt parti.

SAP:s tidigare marxistiska klasskämpar var däremot Wiiks ideologiska meningsfränder, de som entusiastiskt gått med i det nya vänstersocialistiska partiet och till kommunisterna, men som mot slutet av I920-talet återvände till socialdemokratin. Till dem hörde Ivar Wennerström, som Wiik bjöd in som talare till Finland under riksdagsvalkampanjen I929. Wennerström skrev en artikel både till Social-Demokraten och Arbetarbladet om sina "intryck från Finland" och fokuserade särskilt på den pågående konflikten mellan finskt och svenskt. I artikeln gjorde Wennerström en sverigesvensk socialdemokratisk läsekrets uppmärksam på faran med de äktfinska angreppen mot finlandssvenskarna, en minoritet som enligt honom, genom att de hörde till tjänstemannaklassen, representerade Finlands "västerländska traditioner av hederlighet, laglydighet och lojalitet" och som hade "en synnerligen stor statsbyggande betydelse" för den unga republiken. Wennerströms argumentation utgick från en likadan syn på svenskhetens kulturella betydelse som Wiik hade och som han värnade om då han talade för svenskhetens bevarande i Finland. Liksom Wiik hade

38. Lindströms bok återfinns i Wiiks personarkiv, men hurdant mottagande den fick hos Wiik är osäkert. Mapp 9 I928-30, K.H. Wiiks arkiv, Riksarkivet, Helsingfors. 
Wennerström sett en förebild i de unga estniska och lettiska staternas konstitutioner som utarbetats utifrån austromarxisten Renners teorier kring kulturell autonomi. Enligt denne hade minoriteterna sammanblandats med majoriteten för att verka inom "den nya statliga ramen" utan "nämnvärda slitningar" mellande de två grupperna. Denna progressiva mångnationella samhällsanda saknades enligt Wennerström helt i Finland, där finnar och svenskar levde "[s]om hund och katt" när de i stället borde samarbeta för republikens sociala utveckling. ${ }^{39}$

Wennerström uttryckte sitt bekymmer för svenskhetens framtid i Finland och såg, på grund av partiets "reaktionära" hållning, inte SFP som en säker garanti för svenskhetens bevarande och utvecklande. Ett "ungdomligt hopp" såg han däremot i den borgerliga svenska vänstern företrädd av "Schauman-radikalismen", som kunde utgöra "den svenska borgerlighetens brygga" till den "svenska socialdemokratin", det vill säga FSA. Wiik och de två övriga ledande namnen i I920talets finlandssvenska socialdemokrati, Axel Åhlström och Karl-August Fagerholm, nämnde Wennerström som de svenska socialdemokrater i Finland som upplyst det svenska småfolket vid kustlandet "där svensknationalismen har uråldrigt starka rötter" och där partiet kunde "skapa växtlighet för den internationella socialismens idéer". Den svenska socialdemokratin i Finland skulle enligt Wennerström kunna skapa ett intimare samarbete mellan de två ländernas socialdemokratiska rörelser "vilket skulle påskynda den europeisering, den medvetna inställning efter västerländskt socialistiska idé- och aktionslinjer" som Wennerström såg att SDP under Wiik strävat efter under årtiondet efter inbördeskriget. ${ }^{40}$

\section{WIIK OCH SOCIALDEMOKRATERNAS INTERNATIONALISM I SKOTTLINJEN}

Då Wiik tillträdde som socialdemokratisk partisekreterare hamnade han inledningsvis i skottlinjen både för sin socialistiska internationalism och för sin finlandssvenskhet. Wiiks första uppträdande i riksdagen efter att han blivit utsedd till partisekreterare ägde rum

39. Ivar Wennerström, "Intryck från Finland", Arbetarbladet Io/7 I929.

40. Ibid. 
då han skulle föra den socialdemokratiska riksdagsgruppens talan i behandlingen av Agrarförbundets motion att begränsa den utländska invandringen till Finland. Frågan gällde i första hand rysk migration som Wiik försvarade, medan agrarerna förundrade sig över att SDP:arna var villiga att anlita billig utländsk arbetskraft medan finska arbetare gick arbetslösa. ${ }^{41}$ Då liksom tidigare hade Wiik kritiserats från högerhåll för sin reservationslösa inställning till invandringen från öst. Denna kritik påminde till vissa delar om den som den svenskspråkiga antisemitiska och konservativa skämttidningen Fyren raljant framfört mot Wiik och hans förslag vid lantdagen I9I3 om att tilldela de ryska judiska immigranterna finländskt medborgarskap vid tiden för den ryska pogromen. ${ }^{42}$

Riksdagsdebatten refererades i den samlingspartistiska tidningen Karjala, där man framför allt gick till personangrepp mot Wiik. Skribenten, signaturen "Esa", undrade varför SDP under partikongressen utmanövrerat den "fenomenale talaren" Taavi Tainio, som före Wiik hade partisekreterarposten, och i stället valt den finlandssvenske Wiik."Esa" beskrev Wiik som "en tyst man som knappt talar hörbart och framstår som osäker också då han läser högt ur sina papper". I Karjala raljerar tidningsredaktören vidare att orsaken till valet av Wiik antagligen var att SDP, som under partikongressen 1926 gjort en klar vänstergir, hade velat få en partisekreterare som hade ett mera "världsrevolutionärt utseende" än den föregående och som med "sitt smala ansikte och sina dystra ögon och sin skarpa blick bakom glasögonen påminde om den kända agitatortypen från det östra grannlandet”. ${ }^{43}$

Den finsknationalistiska högertidningen Aitosuomalainen (sv. Äktfinnen) förundrades likaså över att det finska SDP valt en "fanatisk svensk" ${ }^{44}$ till partisekreterare framom de äkta finska män som väl

4I. "Esa", "Parlamenttipakinaa", Karjala I8/2 I926.

42. Fyren $5 / 4$ I9I3.

43. "Esa","Parlamenttipakinaa"."Eduskunnan loistavimpia puhujia";"Hän on hiljainen, puhuu tuskin kuultavasti ja on epävarma paperistakin lukiessaan.";"maailmanvallankumouksellisen agitaattorin näköinen"; "Laihat kasvot ja synkät silmät sekä tuikea katse silmälasien takaa muistuttavat tunnettua agitaattorityyppiä itäisestä naapurimaasta”. Översättning: MK.

44. "Ruotsalainen mies sosialidemokraattienkin johtoon", Aitosuomalainen 3/1926. "Kiihkoruotsalainen". Översättning: MK. 
fanns i partiets led, och tidningen undrade: "Varför då hålla sig till lånegods?" 45 Finskheten hade med valet av"maisteri Viik" (sv. magistern Viik) åter lidit ett nederlag, då socialdemokraterna gått i den fälla som gillrats av svenskarna. Antisvenskheten förstärktes med tidningens bruk av antisemitisk retorik: finlandssvenskarna jämfördes med judarna och deras påstådda världskonspiration och antinationalism. Likt judarna som styrde "den internationella proletariatdiktaturen" i Sovjet, agerade finlandssvenskarna på motsvarande sätt genom den finländska arbetarrörelsen för att underminera det finska folkets enighet. ${ }^{46}$

Den äktfinska högerns och borgerlighetens antisemitism och nationalism uttrycktes i flera ironiskt skämtsamma pressinlägg. Bland annat i finska journalistförbundet Suomen Sanomalehtimiesliittos skämttidning Tuulispää framställdes SDP som ett"sant internationellt parti, åtminstone vad beträffar dess ledning”. På en karikatyrteckning i Tuulispää den I8 oktober 1929 figurerade förutom "svensken" Wiik även Mikko Erich, i vars ådror man påstod att det strömmade"en rätt stor dos israeliskt blod" ${ }^{47}$, och rysk-polske Reinhold Svento (tidigare Sventorzetski), om vilken man skrev att han liksom Wiik och Erich inte var av ett sant finskt ursprung. Förutom att dessa tre personer avbildades för att de hörde till partiets mest framträdande vänstersocialdemokrater vid den här tiden (Wiik och Svento) och försvarare av demokratin mot det fascistiska hotet (Erich), användes rasistisk och antisemitisk karikatyr i porträtteringen av åtminstone Erich och Svento. Bildens budskap var det som redan framträtt tidigare i den äktfinska högerkritiken av bland andra Wiik, det vill säga att SDP styrdes av en ofosterländsk, antifinsk, internationell, sammansvuren grupp av representanter för främmande icke-finska minoriteter som utgjorde ett hot mot det finska Finland.

Även vänstersocialisterna gick till angrepp mot Wiiks och socialdemokraternas internationalism. På finlandssvenskt vänstersocialistiskt och kommunistiskt håll påstod man att Wiik blivit finsknationalistiskt antisvensk. Enligt den finlandssvenska kommunisttidningen Nya Folkbladet hade det gått så långt att Wiik använt den förfinskade

45. Ibid. "Miksi turvaudutaan lainatavaraan?” Översättning: MK.

46. Ibid.

47. Tuulispää I8/ıо 1929. "suonissa virrannee melko annos israelilaista verta". Översättning: MK. 
signaturen "Kaarlo Viik”. De finlandssvenska kommunisterna var på alerten under denna tid då vänstersocialister eller kommunister också på finlandssvenskt håll kämpade om arbetarnas stöd. Genom att vädja särskilt till de svenskspråkiga arbetarnas minoritetsnationalism angrep Nya Folkbladet klassförrädarna i SDP och anklagade dem för finsknationalism och de svenska socialdemokraterna, däribland Wiik, för sin undfallenhet gentemot förfinskningen av det svenska Finland. ${ }^{48}$

I en pamflett med titeln Ett diskussionsinlägg $i$ nationalitetsfrågan, som publicerades under riksdagsvalskampanjen 1927, gick den österbottniske vänstersocialisten och riksdagsmannen Johan August Isaksson till angrepp mot SDP:s nationalitetspolitik. Isaksson framträdde själv som hängiven anhängare av svenskt självstyre som försvar mot hotande äktfinsk nationalism. Mot vänstersocialisternas försvar av svenskheten i Finland och det svenska folkets rättigheter stod framför allt SDP. Enligt Isaksson förespråkade partiet ett "samgående mellan finnar och svenskar", vilket of rånkomligen skulle leda till att den svenska minoriteten kvävdes under den finska majoriteten. Genom samarbetet med de finsknationalistiska borgerliga partierna kunde SDP "tumma på den svenska nationalitetens gemensamma intressen". ${ }^{49}$ Isakssons kritik ska läsas mot bakgrund av Finlands kommunistiska partis och Kominterns kritiska offensiv I926-I927 mot austromarxisterna och dess inflytande på Kominterns rival SAI och de socialdemokratiska partierna, inklusive finländska SDP. ${ }^{50}$ Också Isaksson tillämpade i sin pamflett ett språkbruk som låg nära Kominterns, när han beskyllde FSA för klassförräderi och för att utvecklingen följde den "finska byråkratins grunduppfattning i nationalitetsfrågan" i Finland samt påpekade "att det här i landet finnes blott en nationalitet, av vilken en del talar finska och en del tills vidare svenska". ${ }^{51}$

Vänstersocialisternas och kommunisternas revolutionära klasskampsretorik fick ge vika då Lapporörelsen gjorde entré på den politiska scenen i november 1929. Även socialdemokraterna blev nu

48. Sign. "Utposten", "Från utkiken”, Nya Folkbladet Io/5 I929.

49. Johan A. Isaksson, Ett diskussionsinlägg i nationalitetsfrågan, Vasa: Ny Tids förlag I927, s. 23 .

50. Tauno Saarela, Suomalainen kommunismi ja vallankumous I923-1930, Helsinki: Suomalaisen Kirjallisuuden Seura 2008, s. I78-I80.

51. Isaksson, Ett diskussionsinlägg i nationalitetsfrågan, s. 24. 
måltavla för den finländska fascismens strävan att en gång för alla sopa fosterlandet rent från socialismen. Från i930 fram till I936, då Wiik ännu verkade som socialdemokratisk partisekreterare, förändrades socialdemokratins politiska kamp till en överlevnadskamp och i synnerhet inför det hot som fascismen alltmera utgjorde mot demokratin i Finland. En liknande kamp fördes även på andra håll, inte minst i den internationella socialdemokratins kärnländer Tyskland och Österrike, där den socialdemokratiska arbetarrörelsen utplånades av nazister och fascister i början av r930-talet. ${ }^{52}$ Också Wiik befarade att hans öde skulle vara beseglat om en fascistisk statskupp genomfördes. Natten innan bondetåget anlände till Helsingfors den 7 juli I930 skrev han avskedsbrev till modern Hanna och hustrun Anna Wiik. ${ }^{53}$ Det fascistiska hotet mot demokratin och arbetarrörelsen framställdes av de finlandssvenska socialdemokraterna alltjämt som ett hot mot den mångnationella staten. I och med detta var det också ett direkt hot mot finlandssvenskarna, den minoritet som enligt Wiik, FSA och många i den svenska borgerligheten ansåg utgöra förtruppen för västerländskt rättsstatstänkande, för västerländsk demokrati och civilisation i Finland. ${ }^{54}$

\section{SAMMANFATTANDE REFLEKTION}

Mellankrigstiden och särskilt årtiondet efter första världskriget var en mycket turbulent period i Finlands och Europas historia. I den här artikeln har två av de stora samhälleliga konflikter som präglade tidsperioden, nationskonflikter och klasskamp, studerats i relation till den finlandssvenska socialdemokratiska politikern Karl Harald Wiik. Wiiks agerande har granskats utifrån ett politiskt-idéhistoriskt perspektiv, där syftet varit att synliggöra den socialdemokratiska nationsidén och dess uttryck i i920-talets Finland. I artikeln problemati-

52. Lauri Karvonen, From White to Blue-and-Black. Finnish Fascism in the Inter-War Era, Commentationes scientiarum socialium 36, Helsinki: Finnish Society of Sciences and Letters I988, s. 2I-25.

53. K.H. Wiik till Hanna Wiik och K.H. Wiik till Anna Wiik 7/7 I930, Mapp I7 Handlingar rörande I930-talet, K.H. Wiiks arkivsamling, Riksarkivet, Helsingfors.

54. Matias Kaihovirta \& Mats Wickström,"Socialdemokratisk och konservativ antifascism i Finland. Karl H. Wiik och Eirik Hornborg inför Lapporörelsen", Historisk Tidskrift for Finland 20I7:I, Tema: Antifascism i Norden, s. 57-6I. 
seras nationsbegreppet utifrån samtida ideologiska ställningstaganden som gjordes av Wiik inom ramen för hans teoretiska och ideologiska tänkande och transnationella idéutbyte. För Wiik existerade det ingen diskrepans mellan nation och klass. I stället var han angelägen om att visa på den sammanflätade relationen mellan dessa och på det som kunde kallas en falsk kollektiv gemenskap i borgerlighetens nationsbegrepp. Wiiks nationalism byggde på den socialdemokratiska idén om internationalism, om nationers rätt att existera i broderskap med andra nationer. Samtidigt öppnar Wiiks tänkande kring nationsfrågan upp för möjligheten att vidga analysen av nation och nationalism. I tidigare forskning har man å ena sidan uppfattat nationalism som en borgerlig konstruktion bortom den socialistiska arbetarrörelsens verksamhetsdomäner, å andra sidan har den socialdemokratiska arbetarrörelsen formulerat ett eget marxistiskt innehåll för nationsbegreppet.

Wiiks tänkande kring nationsfrågan kom till uttryck under de finländska socialdemokraternas regeringsperiod I926-I927, då Wiik själv såg en möjlighet att skapa en demokratisk front mot en nationalistisk antidemokratisk höger. I hans tänkande finns influenser från bland annat austromarxismen och dess strävan att i österrikisk socialdemokrati skapa klassöverskridande samarbete med borgerliga centerpartier och medvetet arbeta för en avpolitisering av nationsfrågan. Wiik verkade mot en äktfinsk nationalism, så benämnd i samtiden, eller finsk majoritetsnationalism med strävan att nationalisera den finska nationalstaten så att den framstod som finsk. Likväl kritiserades Wiik och SDP för sin internationalism och sitt försvar av den bi-nationella regeringsformen. Kritikerna till vänster om socialdemokratin hävdade att Wiik övergett kampen för den svenskspråkiga minoritetens rättigheter.

Den svenske partisekreteraren Wiik representerade inte bara den svenska minoritetsnationens arbetarklass, utan även, med en samtida austromarxistisk benämning, en "svensk karaktärsgemenskap". För Wiik liksom för austromarxisterna, skulle socialdemokratin inkludera samtliga folk (oavsett språklig, etnisk och religiös tillhörighet) i en gemensam högre kultur, för att tillsammans uppnå mänsklighetens högre kulturella civilisationsnivå, det vill säga socialismen. Samtidigt fanns det ett ingrott etniskt förhållningssätt hos austromarxisterna i synen på kultur, där den nationella kulturen, den tysk-österrikiska 
som de representerade, framstod som den normativa måttstocken för civilisation och utveckling. Det samma gällde Wiik i hans syn på svenskhet och de svenska värderingar som han ville framhålla som partisekreterare för SDP. 